\title{
Relation between raised concentrations of fucose, sialic acid, and acute phase proteins in serum from patients with cancer: choosing suitable serum glycoprotein markers
}

\author{
GA TURNER, ${ }^{*}$ AW SKILLEN, ${ }^{*}$ P BUAMAH, $\dagger$ D GUTHRIE, J WELSH,§ J HARRISON, \\ A KOWALSKI* \\ From the *University Department of Clinical Biochemistry and Metabolic Medicine, Royal Victoria \\ Infirmary; †Department of Chemical Pathology, Freeman Road Hospital; $\ddagger$ Radiotherapy Centre, Newcastle \\ General Hospital, Newcastle upon Tyne, and \$Department of Clinical Oncology, Gartnavel General Hospital, \\ Glasgow
}

SUMMARY Serum concentrations of fucose, sialic acid, and eight acute phase proteins were measured in single specimens from patients with cancer in order to determine whether the raised concentrations of protein bound sugars commonly found in cancer correlate with increased concentrations of the acute phase proteins. Strong positive correlations were found only with $\alpha_{1}$-acid glycoprotein, $\alpha_{1}$-antitrypsin, and haptoglobins. Changes in protein bound sugars and acute phase proteins were also examined in relation to patients' disease states. Serum fucose was raised more often in patients with advanced disease than in those in whom the spread of the tumour was more restricted; increased sialic acid concentrations, however, were found with a similar frequency in both these groups. Combined use of fucose and sialic acid values gave a high degree of marker positivity which could be only slightly improved on by including measurement of acute phase proteins. The combined use of serum fucose and sialic acid concentrations may have value in monitoring patients with cancer: the sialic acid provides an index of the acute phase response and the fucose a measure of the tumour spread.

Serum fucose ${ }^{12}$ and sialic acid ${ }^{34}$ concentrations are often increased in patients with cancer, but there is no satisfactory explanation for these changes. There are many possibilities: increased glycosylation of serum glycoproteins; shedding of glycoproteins from the tumour cell surface; and increased concentrations of normal serum glycoproteins. The object of this study was to examine the possibility that increased concentrations of the so called acute phase proteins are responsible for the increased concentrations of fucose and sialic acid. Many acute phase proteins have raised values in patients with cancer, ${ }^{5}$ and some of these have a high carbohydrate content. $^{6}$

\section{Material and methods}

Blood specimens were collected from 274 healthy

Accepted for publication 23 January 1985 volunteers (79 men and 195 women; age range 18$65)$ who were attending blood donor sessions and 182 patients with cancer ( 35 men and 147 women; age range 14-75). The latter were either in hospital or attending outpatient clinics. Some were already receiving treatment and others had yet to start. Serum was separated by centrifugation and stored at $-20^{\circ} \mathrm{C}$ until required for assay.

Table 1 gives details of the cancer group. The early subgroup consisted of women with positive cervical smears who were subsequently proved to have cervical intraepithelial neoplasia. The clinical subgroup consisted of patients with cancers that had arisen in various sites, who either had a small localised mass or successful treatment for more extensive disease. The advanced subgroup consisted of patients who either had an untreated extensive growth or progressive growth that was not responding to treatment; again, the cancers had arisen in various sites.

The concentrations of fucose, protein, and sialic 
Table 1 Details of patients with cancer

\begin{tabular}{lcccc}
\hline Primary tumour site & \multicolumn{2}{c}{ Patients' disease states } & \\
\cline { 2 - 5 } & Early & Clinical & Advanced & Unknown \\
\hline Breast & 0 & 7 & 11 & 3 \\
Cervix & 22 & 16 & 1 & 5 \\
Gastrointestinal & 0 & 1 & 7 & 5 \\
Lung & 0 & 0 & 5 & 0 \\
Lymphoid & 0 & 2 & 6 & 0 \\
Melanoma & 0 & 1 & 4 & 0 \\
Ovarian & 0 & 16 & 3 & 4 \\
Vagina/vulva & 0 & 0 & 2 & 5 \\
Miscellaneous & 0 & 7 & 12 & 1 \\
Unknown & 0 & 0 & 2 & 34 \\
\hline
\end{tabular}

${ }^{*}$ See text for further information on definition of groups.

acid were determined in all the serum samples collected. The concentrations of eight acute phase proteins, $\alpha_{1}$-acid glycoprotein, $\alpha_{1}$-antitrypsin, caeruloplasmin, haemopexin, haptoglobins, $\alpha_{2}$-macroglobulin, prealbumin, and transferrin, were determined in 37 samples from the healthy group and 121 samples from the patients with cancer. Apart from excluding women taking oral contraceptives, specimens were chosen at random.

Serum fucose concentrations were measured using a fucose dehydrogenase method similar to that described elsewhere. ${ }^{7}$ Briefly, $0.1 \mathrm{ml}$ of serum was incubated with $0.9 \mathrm{ml}$ of $0.155 \mathrm{~mol} / \mathrm{H} \mathrm{H}_{2} \mathrm{SO}_{4}$ at $100^{\circ} \mathrm{C}$ for $1 \mathrm{~h}$. The acidified serum was neutralised with saturated barium hydroxide to a total volume of $1.8 \mathrm{ml} ; 0.2 \mathrm{ml}$ of this supernatant was added to
$0.45 \mathrm{ml}$ of $0.2 \mathrm{mmol} / 1 \mathrm{Tris} / \mathrm{HC} 1, \mathrm{pH} 8.2,0.25 \mathrm{ml}$ of $0.8 \mathrm{mg} / \mathrm{ml} \quad$ L-fucose dehydrogenase (Miles Laboratories), and $0.1 \mathrm{ml}$ of $10 \mathrm{mmol} / 1$ nicotinamide adenine dinucleotide. The sample was left at room temperature for $60 \mathrm{~min}$, and the fluorescence was then measured at $525 \mathrm{~nm}$ after excitation at $340 \mathrm{~nm}$. The fucose content was estimated by comparison with aqueous fucose standards. All values were corrected using serum blanks in which the proteins were unhydrolysed. The sialic acid content of serum was determined using a periodate/thiobarbituric acid method. ${ }^{8}$ Before assay the protein bound sialic acid was released by hydrolysing $50 \mu \mathrm{l}$ of serum in $2 \mathrm{ml}$ of $0.05 \mathrm{~mol} / 1 \mathrm{H}_{2} \mathrm{SO}_{4}$ at $80^{\circ} \mathrm{C}$ for $1 \mathrm{~h}$. No free sialic acid was detected in unhydrolysed sera, and all specimens were corrected for deoxyribose contami-

Table 2 Serum concentrations of fucose, sialic acid, and certain acute phase proteins in patients with cancer

\begin{tabular}{|c|c|c|c|c|c|c|}
\hline \multirow{3}{*}{$\begin{array}{l}\text { Substance } \\
\text { assayed }\end{array}$} & \multicolumn{5}{|c|}{ Serum concentration } & \multirow{3}{*}{$\begin{array}{l}\text { Percent increase } \\
\text { in patients with } \\
\text { cancer } \dagger\end{array}$} \\
\hline & \multicolumn{3}{|c|}{ Patients with cancer } & \multicolumn{2}{|c|}{ Reference group } & \\
\hline & Mean & $\pm S D$ & Range & Mean & Upper limit ${ }^{*}$ & \\
\hline $\begin{array}{l}\text { Fucose (mg/g protein) } \\
\text { (182) }\end{array}$ & $2 \cdot 1$ & $1 \cdot 0$ & $0 \cdot 69-6 \cdot 4$ & $1 \cdot 1$ & $1 \cdot 8$ & $45 \cdot 6$ \\
\hline $\begin{array}{l}\text { Sialic acid (mg/g protein) } \\
\text { (179) }\end{array}$ & $9 \cdot 2$ & $3 \cdot 3$ & $3 \cdot 3-24 \cdot 5$ & $5 \cdot 9$ & $9 \cdot 4$ & $35 \cdot 2$ \\
\hline Acute phase proteins ( $g / 1$ serum) & & & & & & \\
\hline $\begin{array}{l}\alpha_{1}-\text { Acid glycoprotein } \\
(120)\end{array}$ & $1 \cdot 2$ & 0.55 & $0.4-2.7$ & 0.8 & $1 \cdot 2$ & $35 \cdot 8$ \\
\hline $\begin{array}{l}\text { Haptoglobins } \\
(120)\end{array}$ & $2 \cdot 7$ & $1 \cdot 6$ & $0 \cdot 38-8 \cdot 3$ & $1 \cdot 6$ & $3 \cdot 3$ & $29 \cdot 2$ \\
\hline $\begin{array}{l}\alpha_{1}-\text { Antitrypsin } \\
(120)\end{array}$ & $3 \cdot 4$ & $1 \cdot 5$ & $1 \cdot 0-7 \cdot 9$ & $2 \cdot 8$ & $4 \cdot 0$ & $25 \cdot 0$ \\
\hline $\begin{array}{l}\text { Haemopexin } \\
(121)\end{array}$ & 0.94 & $0 \cdot 17$ & $0 \cdot 26-1 \cdot 5$ & 0.99 & $1 \cdot 3$ & $6 \cdot 7$ \\
\hline $\begin{array}{l}\text { Caeruloplasmin } \\
\text { (117) }\end{array}$ & $0 \cdot 40$ & $0 \cdot 10$ & $0.17-0.70$ & $0 \cdot 36$ & 0.58 & $3 \cdot 4$ \\
\hline $\begin{array}{l}\alpha_{2}-\text { Macroglobulin } \\
(112)\end{array}$ & $2 \cdot 2$ & $0 \cdot 58$ & $0 \cdot 77-4 \cdot 4$ & $2 \cdot 5$ & $4 \cdot 0$ & $0 \cdot 9$ \\
\hline $\begin{array}{l}\text { Prealbumin } \\
\text { (113) }\end{array}$ & $0 \cdot 23$ & $0 \cdot 08$ & $0.04-0.42$ & $0 \cdot 34$ & 0.45 & 0 \\
\hline $\begin{array}{l}\text { Transferrin } \\
\text { (121) }\end{array}$ & $2 \cdot 6$ & $0 \cdot 71$ & $0 \cdot 69-4 \cdot 5$ & $3 \cdot 7$ & $4 \cdot 8$ & 0 \\
\hline
\end{tabular}

Values given in parentheses indicate the number of sera assayed. Reference values for fucose, sialic acid, and acute phrase proteins are based on 270,261 , and 37 estimations respectively.

*Upper $95 \%$ confidence limit.

†Percent raised above the given confidence limit. 
Table 3 Correlations between protein bound sugars and the acute phase proteins in serum samples from patients with cancer

\begin{tabular}{|c|c|c|c|}
\hline \multirow[t]{2}{*}{ Acute phase protein } & \multirow[t]{2}{*}{ No of pairs* } & \multicolumn{2}{|c|}{ Correlation coefficient } \\
\hline & & Fucose & Sialic acid \\
\hline $\begin{array}{l}\alpha_{1} \text {-Acid glycoprotein } \\
\text { Haptoglobins } \\
\alpha_{1} \text {-Antitrypsin } \\
\text { Haemopexin } \\
\text { Caeruloplasmin } \\
\alpha_{2} \text {-Macroglobulin } \\
\text { Prealbumin } \\
\text { Transferrin }\end{array}$ & $\begin{array}{l}118 \\
120 / 118 \\
120 / 118 \\
120 / 118 \\
115 \\
112 \\
113 \\
120 / 118\end{array}$ & $\begin{array}{l}+0.60 \dagger \\
+0.47 \dagger \\
+0.44 \dagger \\
+0.31 \dagger \\
+0.26 \\
-0.24 \\
-0.45 \dagger \\
-0.38 \dagger\end{array}$ & $\begin{array}{l}+0.65 \dagger \\
+0.53 \dagger \\
+0.54 \dagger \\
+0.38 \dagger \\
+0.17 \\
-0.35 \dagger \\
-0.47 \dagger \\
-0.50 \dagger\end{array}$ \\
\hline
\end{tabular}

${ }^{*}$ A single value indicates that the number of pairs were the same for each sugar.

†Indicates that correlations are statistically significant $(p<0.025)$.

nation. Serum concentrations of fucose and sialic acid are expressed as $\mathrm{mg} / \mathrm{g}$ serum protein.

Protein was determined by the biuret method." The serum protein concentrations for the healthy and cancer groups were $68.6 \mathrm{~g} / \mathrm{l}(\mathrm{SD} 4.8 \mathrm{~g} / \mathrm{l} ; \mathrm{n}=$ $269)$ and $65.0 \mathrm{~g} / \mathrm{l}(\mathrm{SD} 7 \cdot 8 \mathrm{~g} / \mathrm{l} ; \mathrm{n}=182)$ respectively.

Acute phase protein concentrations were estimated by radial immunodiffusion (Partigen Plates, Hoechst Pharmaceuticals). Standards were obtained from Hoechst and the results were expressed as $\mathrm{g} / \mathrm{l}$. The interassay coefficients of variation for the fucose, sialic acid, and acute phase protein assays were about $10 \%, 8 \%$, and $5 \%$ respectively.

\section{Results}

Table 2 summarises the results of measurements of the serum concentrations of fucose, sialic acid, and the acute phase proteins in patients with cancer. The protein bound sugars were measured in more patients than the acute phase proteins. Using results of protein bound sugars only when acute phase protein values were available, however, made little difference to the data as presented. The mean values and the upper $95 \%$ confidence limits of the healthy group are also given in Table 1 for comparison. The upper reference limits found were similar to those previously quoted for acute phase proteins (Beringwerke, Hoechst Pharmaceuticals), fucose, ' and sialic acid. ${ }^{4}$ Only three of the acute phase proteinsnamely, $\alpha_{1}$-acid glycoprotein, $\alpha_{1}$-antitrypsin, and haptoglobins-had appreciably raised concentrations and only the $\alpha_{1}$-acid glycoprotein was raised as often as the protein bound sugars. Increased fucose concentrations were the most common finding, occurring in about half of the patients with cancer.

Table 3 shows the correlations between the concentration of fucose or sialic acid and the concentrations of the different acute phase proteins in individual patients with cancer. The data fall into three groups: one group $\left(\alpha_{1}\right.$-acid glycoprotein, $\alpha_{1}$ groups; one group $\left(\alpha_{1}\right.$-acid glycoprotein, $\alpha_{1-}$ antitrypsin, haptoglobins) in which the association is strongly positive; another group (prealbumin, transferrin), in which the association is strongly negative; and a third group (caeruloplasmin, haemopexin, $\alpha_{2}$-macroglobulin), in which the association is much weaker. Measurements on healthy serum samples did not indicate any strong correlations except in the case of haemopexin, which appeared to correlate strongly with both sugars (data not given).

Table 4 shows the degree of increase of the protein bound sugar in the patients with cancer according to patients' disease states. The number of patients in each subgroup with raised fucose concentrations increases with tumour progression, with a $70 \%$ increase in those with more advanced disease. On the other hand, the number of patients

Table 4 Effect of disease states of patients with cancer on the serum concentrations of fucose and sialic acid

\begin{tabular}{|c|c|c|c|c|c|}
\hline \multirow{2}{*}{$\begin{array}{l}\text { Patient } \\
\text { group }\end{array}$} & \multicolumn{2}{|l|}{ Fucose } & \multicolumn{2}{|l|}{ Sialic acid } & \multirow{2}{*}{$\begin{array}{l}\text { Fucose or sialic } \\
\text { acid raised (\%)† }\end{array}$} \\
\hline & $\begin{array}{l}\text { Mean concentration } \\
(m g / g)\end{array}$ & No raised $\dagger(\%)$ & $\begin{array}{l}\text { Mean concentration } \\
(\mathrm{mg} / \mathrm{g})\end{array}$ & No raised $\dagger(\%)$ & \\
\hline $\begin{array}{l}\text { Early (22) } \\
\text { Clinical (50) } \\
\text { Advanced (53) }\end{array}$ & $\begin{array}{l}1 \cdot 5 \pm 0.7 \\
2 \cdot 1 \pm 0 \cdot 88 \\
2 \cdot 8 \pm 1 \cdot 2\end{array}$ & $\begin{array}{l}18 \cdot 2 \\
58 \cdot 0^{*} \\
69 \cdot 8\end{array}$ & $\begin{array}{r}7 \cdot 1 \pm 1.5 \\
10.4 \pm 3.7 \\
10.3 \pm 3.6\end{array}$ & $\begin{array}{c}9-1 \\
54 \cdot 0^{*} \\
52 \cdot 8^{*}\end{array}$ & $\begin{array}{l}27 \cdot 3 \\
82 \cdot 0 \\
73 \cdot 6\end{array}$ \\
\hline
\end{tabular}

Values in parentheses indicate the number of patients in each group. Mean \pm standard deviation.

*Indicates a significant difference between the group marked and the respective combined marker group (p $<0.025 ; \chi^{2}$ test).

tAbove the upper limit of the reference range. 
Table 5 Fucose, sialic acid, and the acute phase proteins as combined markers of malignancy

\begin{tabular}{|c|c|c|c|}
\hline \multirow[t]{2}{*}{ Parameters measured } & \multicolumn{3}{|c|}{ No of patients with raised values } \\
\hline & Early (22) & Clinical (50) & Advanced (53) \\
\hline $\begin{array}{l}\text { Fucose } \\
\text { Fucose and sialic acid }\end{array}$ & $\begin{array}{l}4 \\
6\end{array}$ & $\begin{array}{l}29 \\
41\end{array}$ & $\begin{array}{l}37 \\
39\end{array}$ \\
\hline $\begin{array}{l}\text { Fucose, sialic acid, and } \\
\alpha_{1}-\text { acid glycoprotein } \\
\text { Fucose, sialic acid } \alpha \text {-acid glycoprotein }\end{array}$ & 6 & 42 & 42 \\
\hline $\begin{array}{l}\text { Fucose, sialic acid, } \alpha_{1}-\text { acid glycoprotein, } \\
\text { and haptoglobins }\end{array}$ & 7 & 42 & 43 \\
\hline $\begin{array}{l}\text { Fucose, sialic acid, } \alpha_{1}-\text { acid glycoprotein, } \\
\text { haptoglobins, and } \alpha_{1} \text {-antitrypsin }\end{array}$ & 7 & 42 & 43 \\
\hline
\end{tabular}

Figures in parentheses are the total number of patients in each group. Acute phase protein measurements were not available for 2,2 , and 7 patients in the early, clinical, and advanced groups respectively.

with raised sialic acid concentrations appears to be the same in the clinical and advanced subgroups. The frequency with which any one of the two sugars was raised in the clinical subgroup was significantly higher than when either sugar was considered singly $\left(\chi^{2}\right.$ test, $p<0.025$; Table 4$)$. No association was found between increased protein bound sugar values and the initial site of tumour growth (data not given).

Table 5 illustrates the effect of combining the results for the sugar assays with those of $\alpha_{1}$-acid glycoprotein, $\alpha_{1}$-antitrypsin, and haptoglobins. The data for the sugars alone has already been given in Table 4. Inclusion of the acute phase protein measurements had little effect on combined marker increase.

\section{Discussion}

Current data suggest that increased concentrations of serum sialic acid in patients with cancer reflect an acute phase response. A strong correlation was noted between three of the acute phase proteins measured ( $\alpha_{1}$-acid glycoprotein, $\alpha_{1}$-antitrypsin, and haptoglobins) and the concentrations of this sugar. Furthermore, using the reported sialic acid content of these proteins, ${ }^{6}$ it could be roughly estimated that the magnitude of their increase was sufficient to account for most of the extra serum sugar.

In a few patients with raised sialic acid concentrations $\alpha_{1}$-acid glycoprotein, $\alpha_{1}$-antitrypsin, and haptoglobins were not increased; in these cases the cause of the raised sialic acid value is unclear. It may be associated with a certain patient type or prognosis. We could not identify from our records any common clinical feature that correlated with the finding. We have limited details on follow up, however, and we intend to study this aspect more closely.

Two previous studies ${ }^{310}$ have attempted to examine the relations between serum sialic acid val- ues and acute phase proteins in cancer. Bradley $\mathrm{et}^{\mathrm{al}^{3}}$ reported correlation coefficients with $\alpha_{1}$-acid glycoprotein, $\alpha_{1}$-antitrypsin, and haptoglobins of $0.95,0.90$, and 0.86 respectively. These are much higher than those found in the present study. This discrepancy may be explained by the fact that Bradley et al used a different method to measure sialic acid. Their method was non-specific and gave serum values that were much higher than those previously reported by other groups. ${ }^{24}$ Another study, ${ }^{10}$ which was limited to malignant melanomas, reported that sialic acid measurements correlated quite strongly with $\alpha_{1}$-acid glycoprotein but did not give a value for the correlation coefficient. No comment was made on the correlation between sialic acid and other acute phase proteins.

Although increased serum fucose concentrations in patients with cancer also correlate with increases in certain acute phase proteins, the correlation coefficients were less than those found for sialic acid. It seems doubtful whether the fucose and acute phase protein changes are directly related because the acute phase proteins concerned contain insufficient amounts of fucose to account for the raised serum value. The acute phase proteins may increase their fucose content in cancer; this possibility is being investigated. It is possible that other serum proteins - for example, antichymotrypsin and immunoglobulins - contribute to the increased fucose concentrations, but it seems unlikely. Either they are infrequently raised in cancer-for example, $\mathrm{IgG}^{3}$ - or they are present in serum in too small amounts to make a significant contribution-for example, $\alpha_{1}$-antichymotrypsin. ${ }^{6}$

The tumour itself may also contribute to circulating fucose concentrations either by spontaneous release of glycoproteins as the mass grows or as a result of cell damage through host attack or treatment. A number of studies ${ }^{11-15}$ have shown that malignant changes may be accompanied by increased expression of membrane associated, 
fucose containing macromolecules. Furthermore, tumours can shed fucosyl containing components into their environment. ${ }^{16}$ Tumours may also contribute indirectly to serum fucose by promoting increased fucosylation of existing glycoproteins. Increased fucosyltransferase values have been noted in malignant tissues ${ }^{17} 18$ and serum samples from patients with cancer. ${ }^{19}$

When the sugar data were classified according to patients' disease states we obtained further support for the idea that serum fucose and sialic acid are increased by different mechanisms. Not only were the patterns of increase for the two sugars different, but also for patients in whom the involvement of the tumour was limited either naturally or by treatment, the increase in fucose concentration often complemented the increase in sialic acid. The combined use of these two markers gave a high degree of positivity that could only be slightly improved on by including the acute phase protein measurements. To the best of our knowledge, the combined use of fucose and sialic acid for monitoring the effects of treatment has not been previously reported. Our results indicate that further investigations are necessary to assess the full potential of this approach.

We gratefully acknowledge the hospital staff in the Glasgow and Newcastle upon Tyne areas for assistance in obtaining blood specimens from patients with cancer; Dr Anne Collins, Director of the Blood Transfusion Service, Newcastle upon Tyne, for help in obtaining blood specimens from healthy individuals; and the North of England Cancer Research Campaign for financial support.

\section{References}

' Tatsumura T, Sato H, Mori A, et al. Clinical significance of fucose level in glycoprotein fraction of serum in patients with malignant tumours. Cancer Res 1977;37:4101-3.

${ }^{2}$ Waalkes TP, Mrochek JE, Dinsmore SR, Tormey DC. Serum protein-bound carbohydrates for following the course of disease in patients with metastatic breast carcinoma. J Natl Cancer Inst 1978;61:703-7.

${ }^{3}$ Bradley WP, Blasco AP, Weiss JF, et al. Correlations among serum protein-bound carbohydrates, serum glycoproteins, lymphocyte reactivity, and tumour burden in cancer patients. Cancer 1977; 40:2264-72.
${ }^{4}$ Hogan-Ryan A, Fennelly JJ, Jones M, Cantwell B, Duffy MJ. Serum sialic acid and CEA concentrations in human breast cancer. Br J Cancer 1980;41:587-92.

${ }^{5}$ Cooper EH, Stone J. Acute phase reactant proteins in cancer. Advances in Cancer Research 1979;30:1-44.

${ }^{\circ}$ Clamp JR. Structure and function of glycoproteins. In: FW Putnam, ed. The plasma proteins, vol 2, 2nd ed. New York: Academic Press, 1975:163-211.

'Tsay GC, Dawson G. A sensitive spectrophotometric method for the detection of L-fucose. Anal Biochem 1977;78:423-7.

${ }^{8}$ Skoza L, Mohos S. Stable thiobarbituric acid chromophore with dimethyl sulphoxide. Application to sialic acid assay in analytical de-o-acetylation. Biochem J 1976;159:457-62.

' Cannon DC, Olitzky I, Inkpen JA. Proteins. In: Henry RJ, Cannon DC, Winkelman JW, eds. Clinical chemistry, 2nd ed. New York: Harper Row Publishers, 1974:405-502.

${ }^{10}$ Silver HKB, Karim KA, Salinas FA. Relationship of total serum sialic acid to sialylglycoprotein acute-phase reactants in malignant melanoma. Br J Cancer 1980;41:745-9.

"Glick MC. Fucosylation-A role in cell function. In: Walborg $\mathrm{EF}$, ed. Glycoproteins and glycolipids in disease processes. Washington DC: American Chemical Society, 1978:405-11.

12 Vischer P, Reutter W. Specific alterations of fucoprotein biosynthesis in the plasma membrane of Morris Hepatoma 7777. Eur J Biochem 1978;84:363-8.

${ }^{13}$ Turner GA, Guy D, Latner AL, Sherbet GV. Cell surface changes associated with the selection of spontaneous metastasis. In: Hellmann K, Hilgard P, Eccles S, eds. Metastasis: clinical and experimental aspects. The Hague: Nijhoff, 1980:222-6.

${ }^{14}$ Kim YS, Kim YW, Siddiqui B, Tsao D. Membrane-associated fucose-containing glycoproteins and glycolipids of cultured epithelial cells from human colonic adenocarcinoma and fetal intestine. Eur J Cancer Clin Oncol 1982;18:1329-36.

${ }^{15}$ Miyauchi T, Yonezawa S, Takamura T, et al. A new fucosyl antigen expressed on colon adenocarcinoma and embryonal carcinoma cells. Nature 1982;299:168-9.

${ }^{16}$ Doetschman TC. Cell surface turnover and shedding of fucosylglycoprotein in L6 cells. Cell Biol Int Rep 1980;4:379-90.

${ }^{17}$ Bauer CH, Vischer PW, Grunholz H-J, Reutter WG. Glycosyltransferases and glycosidases in Morris hepatomas. Cancer Res 1977;37:1513-8.

${ }^{18}$ Chatterjee SK, Kim U. Fucosyltransferase activity in metastasizing and non-metastasizing rat mammary carcinomas. $J$ Natl Cancer Inst 1978;61:151-62.

19 Bauer CH, Kottgen E, Reutter W. Elevated activities of -2 and -3-fucosyltransferases in human serum as an indicator of malignancy. Biochem Biophys Res Comm 1977;76:488-94.

Requests for reprints to: Dr GA Turner, Department of Clinical Biochemistry and Metabolic Medicine, The Medical School, Newcastle upon Tyne NE2 4HH, England. 